\title{
The impact of Rational-Emotive Counseling Group Model to Modify the Delinquency of Javanese Students
}

\author{
Imam Tadjri ${ }^{1}$, Evi Kartika Chandra ${ }^{2}$ \\ Universitas Negeri Semarang, Indonesia ${ }^{1}$ \\ Institut Agama Islam Ma'arif NU (IAIMNU) Metro Lampung, Indonesia ${ }^{2}$ \\ @ tadjriimam@yahoo.com ${ }^{1}$
}

\author{
Article Information: \\ Received February 25, 2018 \\ Revised June 3, 2018 \\ Accepted July 17, 2018 \\ Keywords: \\ rational-emotive counseling, \\ group setting, juvenile \\ delinquency.
}

\begin{abstract}
A Model of Rational-Emotive Counseling Group to Modify the Delinquency of Javanese Senior High School Students in Semarang City. Delinquency is a maladaptive action with both psycho-individual and psycho-social consequences. The factor that can cause student delinquency is the irrational belief. This research aimed to test the effectiveness of rationalemotive counseling group model in modifying delinquency. This research was conducted using quasi experiment with "patched-up" design. As a whole, the results of the research show that: 1 . Rational-Emotive Counseling Group model is the result of RET application in a group setting, whose components include: structure, input, process, output, evaluation, and follow-up, 2. Rational-Emotive Counseling Group is effective in modifying of delinquency. Further research should be conducted on different ethnicities, educational levels, and types of school.
\end{abstract}

\section{INTRODUCTION}

In Javanese society, parents always hope (digadhang) that their descendants are expected to become people (dadi wong) who according to Javanese philosophy is to be human beings who capable to beautify the life of the world (hamemayu hayuning bawana) so that their life is calm and serene (ayem tentrem) as a life characterized by (1) having the ability to serve and unite with Gusti (manunggaling kawula Gusti), (2) to respect the ancestors and not to bring up the ugliness of parents (mikul dhuwur mendhem jero), (3) to behave with others (hamemayu hayuning bebo), (4) maintaining the honor of self and others (hamemayu hayuning projo), (5) understanding and implementing the honor system (Achmadi, 2004; Mulder, 1985).

If the characteristics are not fully visible then the child is said to have not really become a Javanese (durung njawani). The virtue of the "wong Jowo" behavior by Suseno (MagnisSuseno, 1984) was packed in a term "ethics" which means "the whole norm and the appraisal of the people is used by the society to know how human should live the life".

The above description is the criterion or standard of Javanese behavior (pakem) that is inherited and maintained from generation to generation through conversation (language), ceremonies, arts, customs and symbols, accompanied by strict discipline without arguing (without reserve) and with respect for the elderly. Such cultural inheritance can be interpreted as coercion which results in disturbance of young people's emotions and cognition as well as creating maladaptive behavior that harms themselves or their environment. The most vulnerable group of people to fail in maintaining and developing their cultural lands is

$\begin{array}{ll}\text { How to cite : } & \text { Tadjri, I. \& Chandra, E. K. (2018). The impact of Rational-Emotive Counseling Group Model to Modify the } \\ & \begin{array}{l}\text { Delinquency of Javanese Students. Islamic Guidance and Counseling Journal, 1(2), 81-88. } \\ \text { https://doi.org/10.25217/igcj.v1i2.225 }\end{array} \\ \text { E-ISSN: } & 2614-1566 \\ \text { Published by: } & \text { Institut Agama Islam Ma'arif NU (IAIMNU) Metro Lampung } \\ \text { Available online: } & \text { https://journal.iaimnumetrolampung.ac.id/index.php/igcj }\end{array}$


adolescent.

High school students are individuals who are in the growth stage of adolescence which is a critical growth stage and have a tendency to be wrong (maladaptive). One form of maladaptive behavior is a misbehavior characterized by anarchic, depressive, and aggressive actions. Data of juvenile delinquency in Central Java in 2004 reached 8,316 people; 70\% of them were sent to homes or rehabilitation sessions, while $24 \%$ were sentenced by juvenile court to jail, and 6\% were sent to juvenile prison (Suwito, 2005). The perpetrators of juvenile delinquency are in part as students who are still actively attending the learning process at school. According to the monitoring, the number of delinquency continues to grow, each year reach about $3.5 \%$ (Herlina, 2005).

The factual condition in school shows that most students who behave mischievously on high school in Semarang do not realize that their actions can have negative consequences for themselves and their environment. This is revealed from the results of "short question" which submitted to 100 high school students in Semarang City showed that: $37.5 \%$ of respondents stated that adolescents life is full of turmoil but does not mean that adolescents always behave mischievously. But the respondents also stated that Javanese culture is difficult, even $53 \%$ of students declare school rules are not on the side of adolescent life but rather the preservation of Javanese Culture. $78 \%$ of respondents also stated that the philosophy of Javanese culture burden the adolescents. Respondents also stated Javanese culture is adhi luhung culture then it is better that adolescents get a better position in life in society.

The data indicated that Javanese high school students in Semarang City are adolescents who feel burdened by their Javanese culture, so they tend to behave defiantly from the culture that taught by their family and they tend to think irrationally about Javanese cultural values. This condition needs to watch out for if the irrational mind is allowed to develop in adolescents, it is feared that it will bring bad consequences in the future life. Here is the importance of research in order to know exactly how the behavior of Javanese high school students and how to deal with deviant behavior of Javanese high school students. The research is compacted in the theme: "The Effectiveness of the Rational-Emotive Counseling Group Model to modify the mischievous behavior of Javanese high school students in Semarang City?". The objectives of this study were to: (1) obtain an effective RationalEmotive Counseling Group model to modify adolescent misbehavior, and (2) to identify the effectiveness of Rational-Emotive Counseling Group in modifying adolescent misbehavior. The hypothesis proposed in this research is "Rational-Emotive Counseling Group model is effective to modify the delinquency of Javanese high school students".

Counseling is one form of psychological service that is intended especially for individuals with problems. As a very important and strategic tool, group counseling has a broad meaning that is:

"Group counseling is a dynamic interpersonal process focusing on concious thought and behavior and involving the therapy functions of permissiveness, orientation to reality, catharcis, and mutual thrust, caring, understanding, acceptance, and support. The therapy functions are created and nurtured in a small group through the sharing of personal concerns with one's peers and the councelor(s). The group counselees are basically normal individuals with various concerns which are not debilitating to the extent requiring extensive personality change. The group counselees may utilize the group interaction to increase understanding and acceptance of values and goals and to learn and/or unlearn certain attitudes and behaviors"(Gazda, 1989).

The definition implies that the individual will receive assistance through the group 
atmosphere for the prevention of healingand directed to the provision of ease in the context of its growth and development. As has been mentioned that the handling of maladaptive behavior caused by the existence of irrational beliefs then effective handling is to use techniques that have perspective rational emotive. One of them is Rational-emotive Therapy (RET) developed by Albert Ellis (Ellis, 1973).

RET is based on two assumptions that human beings are born with the potential of thinking, whether rational or straight as well as irrational or bent. Rational thinking is reflected in the tendency to maintain the continuity of state, existence, happiness, the opportunity to think and express in words, to love, to communicate with others, and to growth and self-actualization. While the irrational impulse is manifested in an inner impulse to selfdestruction, to avoid thinking about something, procrastinating, repeatedly making mistakes, believing in superstitions, lacking tolerance, being a perfectionist and self-blame, and avoiding the actualization of potential growth (Corey, 2012).

The irrational belief that causes emotional disturbance may have mixed with the things that come from outside of human beings but humans persist in an attitude that tends to overpower the self by a process of self-indoctrination. People become disturbed not by things, but by what they perceive of them ("It's never the things that happen to you that upset you; its your view of them"). To overcome the indoctrination that leads to irrational thinking, RET therapists (counselors) work with active and directive techniques such as teaching, advising, persuading and giving homework assignments, and challenging clients to replace irrational beliefs with the rational (Natawidjaja, 1987).

Delinquency can also be interpreted as the emergence of attitudes, individual acts that can already be categorized as mischievous including unreliable misbehavior. The tendency of delinquency with high intensity will lead to greater opportunities to take, choose bad and negative actions in the form of anarchic, depressive and aggressive actions (Atkinson, 1999; Kartono, 2003). As discussed in many works of literature that the main task of adolescents in society is looking for answers to the question "Who am I?". The question has appeared in humans for centuries, whether through novels, poetry or autobiography, but has been intensively studied systematically over the last few decades by psychoanalyst (Mussen, Conger, \& Kagan, 1963). Adolescents who have a strong sense of identity (ego), will see themselves as distinctive and separate individuals.

The main conflict of adolescents is the formation of self-identity versus role confusions caused by (1) prematurely stalled, and (2) stretched for time (Erikson, 1968). To help adolescents cope with adolescent conflict, they need to be involved in jobs communities such as volunteering in various fields of activity. This program has been tested and proved by a high school in Chicago-United States that is very famous for the high level of juvenile delinquency.They will get high marks if they succeed in completing the tasks. As a result, failing a class and drop-outs became dramatically reduced, vandalism disappeared, unemployment declined, juvenile delinquency was drastically reduced (Conger, 1977). This kind of project is profitable for the company because it can get young people who are ready to work.

In Javanese society, parents always hope that their descendants will be expected (digadhang) to be being a man (dadi wong) that is perfect human by birth and mind, that is pious to Allah and useful for other human life. To achieve this expectation, Javanese parents not only take care of their welfare, they educate them to become Javanese human beings (wong Jowo) but also equip them with ceremonies since the child was born (metu), married (manten), died as a provision to traverse life someday (Mulder, 1985).

Being a man (dadi wong) according to Javanese philosophy is to be a human being capable of beautifying the life of the world (hamemayu hayuning bawana) in order to live calm and serene (ayem tentrem) with a characteristic life (Achmadi, 2004; Mulder, 1985): 
having the ability to serve and unite with Gusti The Ruler of nature (manunggaling kawula Gusti), respecting the ancestors and not bringing up the ugliness of parents (mikul dhuwur mendhem jero), behaving as well as possible (memayu hayuning saliro) in friendship of fellow (memayu hayuning bebrayan), maintaining self-respect and honor of others (memayu hayuning projo), understanding and carrying out the honor (unggah-ungguh). If the characteristics are not fully visible, then the child is said to have not really become a Javanese (durung njawani). The virtue of the "wong Jowo" behavior was packed in one term "ethics" which means "the whole norm and the appraisal of the people that is used by the society to know how human should live the life" (Magnis-Suseno, 1984).

Counseling as a profession that helps deal with problems of mental disorders is generally performed by normal people, is obliged to help individuals modify maladaptive behavior into adaptive behavior. Maladaptive behavior can arise because of the irrational belief in the individual. High school students are individuals who are in the stage of adolescent growth. In Javanese society, cultural heritage to the younger generation can take place with strict discipline. They are often too convinced that Javanese culture is an "adhi luhung" culture that makes them too proud without reserve. As a result, they hardly ever see any negative values in the Javanese culture that it is necessary to abandon (Suwito, 2004).

\section{METHOD}

This research was conducted by "mixed method research design" in two stages: (1) first stage, preliminary study with qualitative approach to obtain Rational-Emotive Counseling Group model; and (2) Second stage, Rational-Emotive Counseling Group with a quasiexperimental approach by using a "Patched-Up" (Campbell \& Stanley, 1963). The first stage was held with the aim to obtain the hypothetical Rational-Emotive Counseling Group model. By analyzing the factual condition academically, the seminar on Javanese juvenile delinquency, then developing Rational-Emotive Counseling Group design, expert validation testing, Rational-Emotive Counseling Group and Focus Group Discussion (FGD) design testing by the practitioner (school counselor), revising Rational-Emotive Counseling Group design until the Rational-Emotive Counseling Group hypothesis model was discovered. The second stage is field test to determine the effectiveness of the Hypothetical Rational-Emotive Counseling Group Model from the limited sample to the wider sample. Field test results were used for the improvement of the Hypothetical Rational-Emotive Counseling Group Model until a validated Rational-Emotive Counseling Group Model can be disseminated for wider purposes. The sample used in this research is Javanese student in Semarang city.

\section{RESULT AND DISCUSSION}

The Rational-Emotive Counseling Group Model is the result of the application and development of the Ratioanal-Emotive Therapy Group Counseling (RECG) Model from Albert Ellis (Ellis, 1973) that organized in group settings and by accommodating Javanese cultural values and focusing on intervention targets priority. Application components include: structure, input, process, output, and follow-up.

The results of field tests on the Rational-Emotive Counseling Group show that RationalEmotive Counseling Group proved to be effective for Javanese high school students delinquency modification as proved by the decreasing intensity of the tendency of anarchic behavior, depressive behavior and aggressive behavior, and effective to increase the intensity of self-concept of juvenile delinquency. The first hypothesis to be tested in this study: "Rational-Emotive Counseling Group is effective to reduce the intensity of anarchist behavior trends". In statistical tests, it is shown that Rational-Emotive Counseling Group is effective in reducing the intensity of anarchist behavior trends. This is proved by the measurement of the intensity of anarchic behavior, in the selected sample groups and the random sample groups 
after they received the Rational-Emotive Counseling Group (RECG) treatment which intensity decreased to about 18.00, in contrast to the sample of groups of students not receiving Rational-Emotive Counseling Group (RECG), the intensity of anarchic action decreased only to the range 30.73 . An anarchist behavior change after the Rational-Emotive Counseling Group is shown in the following figure:

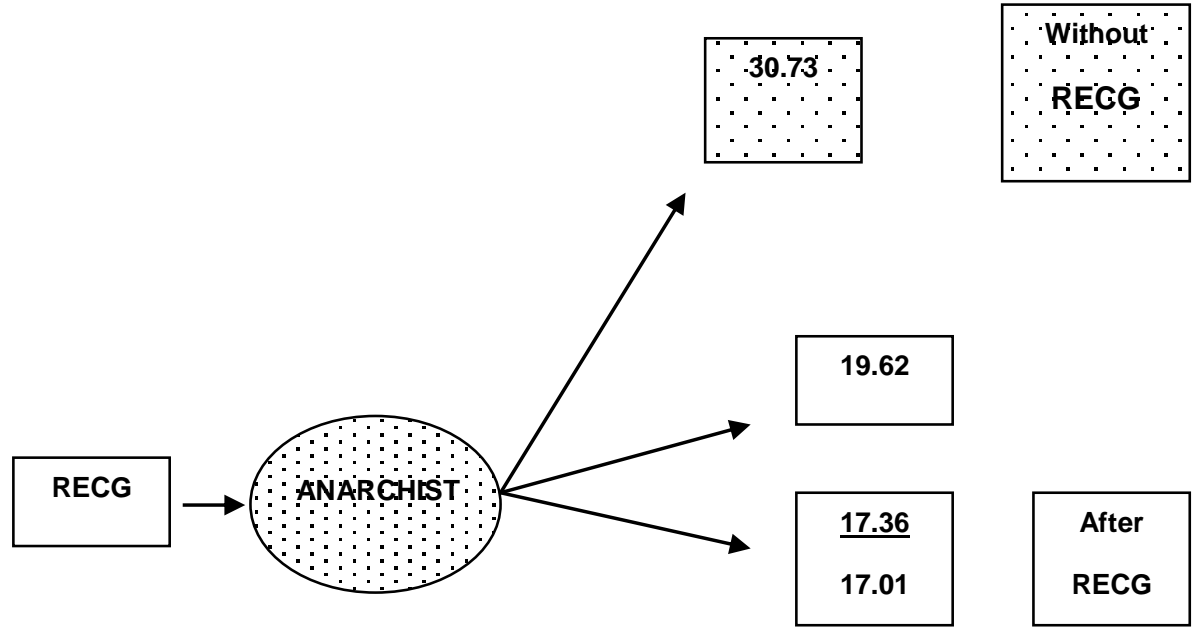

Picture 1. Changes in the intensity of anarchist behavior after the Rational-Emotive Counseling Group.

Modification of bad behavior ever performed by Marcia (in Archer, 1994) with the Rational-Emotive Counseling Group technique in dealing with individuals who experience an identity crisis. In the process of Rational-Emotive Counseling Group, individuals are encouraged to be able to comprehensively understand their perceptions and understandings about themselves and their environment, skillfully engaging in role exploration and commitment, encouraging feedback from peer environments. RET counseling can be constructed as an effective group setting to encourage students who tend to have delinquency to change their irrational views and beliefs, rearrange their cognition, emotions, and actions so that they have the right beliefs, cognitions and behaviors about themselves and their environment in accordance with reality (Corey, 2012; George \& Cristiani, 1981).

In relation to efforts in decreasing the intensity of depression behavior through Rational-Emotive Counseling Group, the hypothesis tested: "Rational-Emotive Counseling Group is effective to decrease the intensity of depressive behavior". The results of the hypothesis test showed that the sample student groups that tend to behave depressively after being subjected to acts of Rational-Emotive Counseling Group showed a decrease in intensity with the average range of 19.27 (O1: 21.35, O4: 19.97, O5: 16.49). This decrease is much different from the sample student group that is not subjected to RECG action, the intensity of depressive behavior only decreased to the range of 32.99 .

Illustration of the decrease in the intensity of depressive behavior between those who received RECG action and those who did not get RECG acts can be seen in the following figure: 


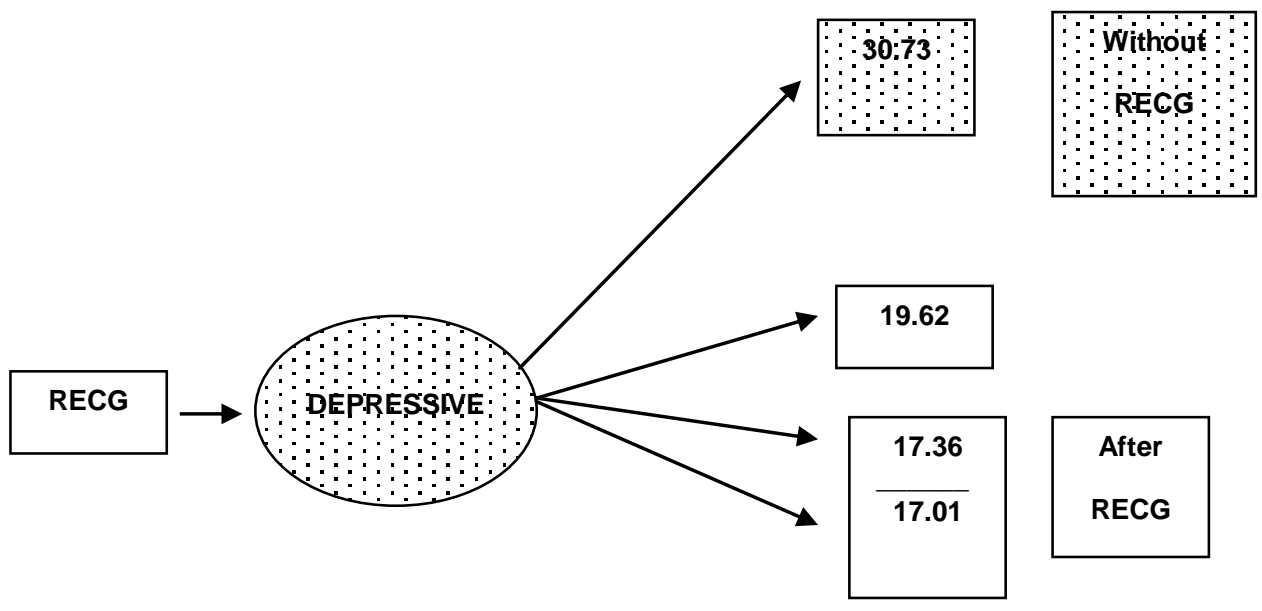

Picture 2. Changes in the intensity of depressive behavior after the Rational-Emotive Counseling Group.

To determine the intensity change in trends of aggressive behavior due to RationalEmotive Counseling Group, the third hypothesis proposed in this study was: "RationalEmotive Counseling Group is effective for lowering the intensity of aggressive behavior". The result of hypothesis test showed that the group of sample students who were given RECG action decreased the intensity of aggressive behavior tendency up to the average level of 19.63 which was far different with the group of students who were not subjected to the action of RECG with the decreased intensity tendency of aggressive behavior only reached level of 30.93 .

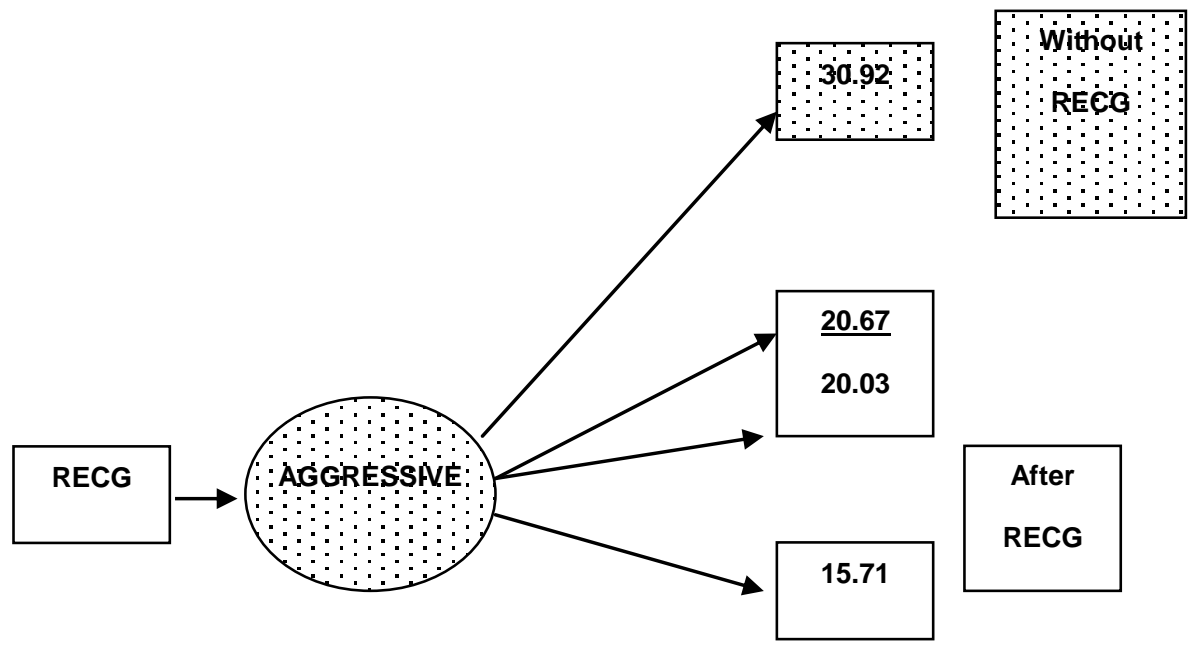

Picture. 3 Changes in the intensity of aggressive behavior after the Rational-Emotive Counseling Group (RECG).

Based on the findings and discussion, Rational-Emotive Counseling Group is believed to be an effective group counseling technique to handle Javanese high school students. However, if the Rational-Emotive Counseling Group will be applied to a wider scope then there are conditions that need to be considered, namely: (a) targeted subjects are Javanese ethnic teenagers, especially Muslims, and those living in Central Java, (b) ) Objectives that become the Rational-Emotive Counseling Group object intervention are maladaptive 
behaviors that originate in irrational beliefs or behavioral problems due to emotional disturbance and cognitive impairment. The organizers of Rational-Emotive Counseling Group are (1) Counselor Teachers/Counselors, especially those in Javanese ethnicity, be in charge and live in Javanese community in Central Java, (2) Understanding Javanese cultural and Islamic values, (3) Experienced in dealing with maladaptive behavior from irrational beliefs, emotional disturbance, or cognitive impairment.

\section{CONCLUSION}

Rational-emotive counseling group model which has been generated in this study proved effective to modify the deliquency of the javanese student. The implication of this conclusion is empirically the Rational-Emotive Counseling Group used in this study is believed to be effective to modify the behavioral tendencies of Javanese high school students. Further implications, Rational-Emotive Counseling Group can be an important alternative to prevent and cope with the misbehavior of high school students and more than that RationalEmotive Counseling Group can be appreciated for prevention of juvenile delinquency in general and in the wider population.

Based on the findings of the study, it is recommended that: (1) Counselor Teachers should use Rational-Emotive Counseling Group to cope with student delinquency, (2) Guidance and Counseling Department to review and compare theory and practice of group counseling with empirical framework of theory and practice has been tested its effectiveness in the field, so it is expected to encourage interest for further research (3) For further research and for interested parties in research of group counseling practices with cognitive-rational perspectives, to conduct research on the same theme in different ethnic populations, different types and different levels of education.

\section{REFERENCE}

Achmadi, A. (2004). Filsafat dan kebudayaan Jawa: upaya membangun keselarasan Islam dan budaya Jawa. Cendrawasih.

Archer, S. L. (1994). Intervention for Adolescent Identity Development. Thousand Oaks, Calif: Sage.

Atkinson, L. (1999). Pengantar Psikologi Jilid 2 (diterjemahkan oleh Nurjannah). Jakarta: Erlangga.

Campbell, D. T., \& Stanley, J. C. (1963). Experimental and quasi-experimental designs for research. Handbook of Research on Teaching. Chicago, IL: Rand McNally.

Conger, J. J. (1977). Adolescence and youth: Psychological development in a changing world. Harper \& Row.

Corey, G. (2012). Theory and Practice of Counseling and Psychotherapy (9th ed.). Canada: Brooks Cole.

Ellis, A. (1973). Rational-emotive therapy. Big Sur Recordings.

Erikson, E. (1968). Youth: Identity and crisis. New York, NY: WW.

Gazda, G. M. (1989). Group counseling: A developmental approach. Citeseer.

George, R. L., \& Cristiani, T. S. (1981). Theory, Methods \& Processes of Counseling \& Psychotherapy. Prentice-Hall.

Herlina. (2005, November 8). Tawuran Antar Pelajar. Kompas, p. 18. 
Kartono, K. (2003). Patologi sosial 3: Gangguan-gangguan kejiwaan. Jakarta: PT. Raja Grafindo Persada.

Magnis-Suseno, F. (1984). Etika Jawa: sebuah analisa filsafi tentang kebijaksanaan hidup Jawa. Gramedia.

Mulder, N. (1985). Pribadi dan masyarakat di Jawa: penjelajahan mengenai hubungannya, Yogyakarta, 1970-1980. Penerbit Sinar Harapan.

Mussen, P. H., Conger, J. J., \& Kagan, J. (1963). Child development and personality.

Natawidjaja, R. (1987). Pendekatan-pendekatan dalam penyuluhan kelompok. Bandung. CV. Diponegoro.

Suwito, Y. S. (2004). Kontribusi Budaya Jawa Dalam Pembangunan. In Wawasan Budaya Untuk Membangun: Menoleh Kearifan Lokal. Yogyakarta: Kembudpar-PSP UGM.

Suwito, Y. S. (2005, March). Gang Cewek "Nero" di Pati. Suara Merdeka, p. 2.

Copyright Holder :
(CTadjri, I. \& Chandra, E. K. (2018)
First Publication Right :
(C) Islamic Guidance and Counseling Journal
This article is under:

